\title{
First evidence for coloniality in sea anemones
}

\author{
Verena Häussermann ${ }^{1,2, *}$, Günter Försterra ${ }^{2}$ \\ ${ }^{1}$ Zoologische Staatssammlung München, Münchhausenstraße 21, 81247 Munich, Germany \\ ${ }^{2}$ Ludwig-Maximilians-Universität München, Department II Biologie, Karlstrasse 23-25, 80333 Munich, Germany
}

\begin{abstract}
Sea anemones, a conspicuous group of marine benthic invertebrates, are considered to be strictly solitary animals. This is in contrast to almost all other orders of the class Anthozoa, which have colony-forming members, the best known examples being reef-building corals. Here we show that the sagartiid sea anemone Cereus herpetodes (McMurrich, 1904) from Chile forms flabello-meandroid colonies through intratentacular budding, a feature hitherto known only from stony corals. This finding sheds new light upon the debated evolution of Anthozoa and the principles of colony formation within this group.
\end{abstract}

KEY WORDS: Colony · Solitary $\cdot$ Actiniaria $\cdot$ Anthozoa $\cdot$ Polystomodaeal intramural intratentacular budding . Fission . Cereus herpetodes $\cdot$ Chile

Resale or republication not permitted without written consent of the publisher

Observations. Colonies of anthozoans are clonal groups of organisms which are physically connected to each other (Fautin 1999). The exclusively solitary growth of sea anemones is well established and has been assumed both in major reference works (Dunn 1982, Shick 1991, Fautin 1999) and in research papers (Francis 1988, Grasshoff \& Gudo 1998, Won et al. 2001, Daly et al. 2002). Herein we present a first report on a colonial sea anemone and briefly discuss the implications of this discovery.

During a 1 yr research project in 1994-1995 and 3 further expeditions to Chile in 1997-1998, 19992000 and 2001, we observed specimens of Cereus herpetodes from the intertidal zone down to depths of $22 \mathrm{~m}$. We found very few solitary individuals. Instead, the anemones form band-like colonies within their entire range of distribution from Arica $\left(18^{\circ} 30^{\prime} \mathrm{S}\right.$, $\left.70^{\circ} 19^{\prime} \mathrm{W}\right)$ to Bahia Tic Toc $\left(43^{\circ} 42^{\prime} \mathrm{S}, 73^{\circ} 00^{\prime} \mathrm{W}\right)$. Flat, irregular, patch-like colonies are restricted to sites subjected to extreme currents; e.g. near Pingueral $\left(36^{\circ} 32^{\prime} \mathrm{S}, 72^{\circ} 55^{\prime} \mathrm{W}\right)$, where clusters of colonies locally cover up to $50 \%$ of rocky surfaces (Fig. 1A). The largest band-like colonies of $C$. herpetodes range up to
$35 \mathrm{~cm}$ in length, and patch-like colonies are up to $17 \times$ $14 \mathrm{~cm}$ in area and $2 \mathrm{~cm}$ tall, with more than 150 mouth openings of different sizes.

Histological sections revealed that multiple mouth openings (Fig. 1B) result from repeated longitudinal fission through the pharynxes; fission proceeds in a proximal to distal direction. The resulting pharynxes are occasionally of similar size, but more often differ substantially (Fig. 1B,C). We observed extremely small pharynxes $<1 \mathrm{~mm}$ in diameter which were connected to only 2 mesenteries and originated from a pharynx 40 times larger in diameter. Pharyngeal fission occurs either between pairs or within pairs of perfect mesenteries (Fig. 1C). After fission of the pharynx is complete, additional mesenteries are inserted and the 2 pharynxes grow slightly apart.

The gastric cavities of the resulting zooids communicate through channels distal to the joint pedal disc. Estimating from their size in preserved specimens, the channels seem too small to allow the passage of larger food particles; however, these openings are large enough to allow the exchange of gastrocoelic fluid. In addition, compared to actiniarians in general, the mesenteries have exceptionally large marginal stomata that facilitate fluid exchange within the colony.

The mode of incomplete fission of polyps in Cereus herpetodes leads to flabello-meandroid colonies (Fig. 1C). It constitutes a mode of colonial growth hitherto known only from stony corals that is described as 'polystomodaeal intramural intratentacular budding' (e.g. genus Euphyllia; Fig. 1D). There is no indication that solitary polyps result from these divisions, but whole polystomodaeal portions of the colonies with independent tentacular crowns seem to separate as a form of asexual proliferation. In several of the colonies examined, most of the zooids had reproductive tissue. This indicates that the polystomodaeal colony is a permanent condition in C. herpetodes, and that colonies of 

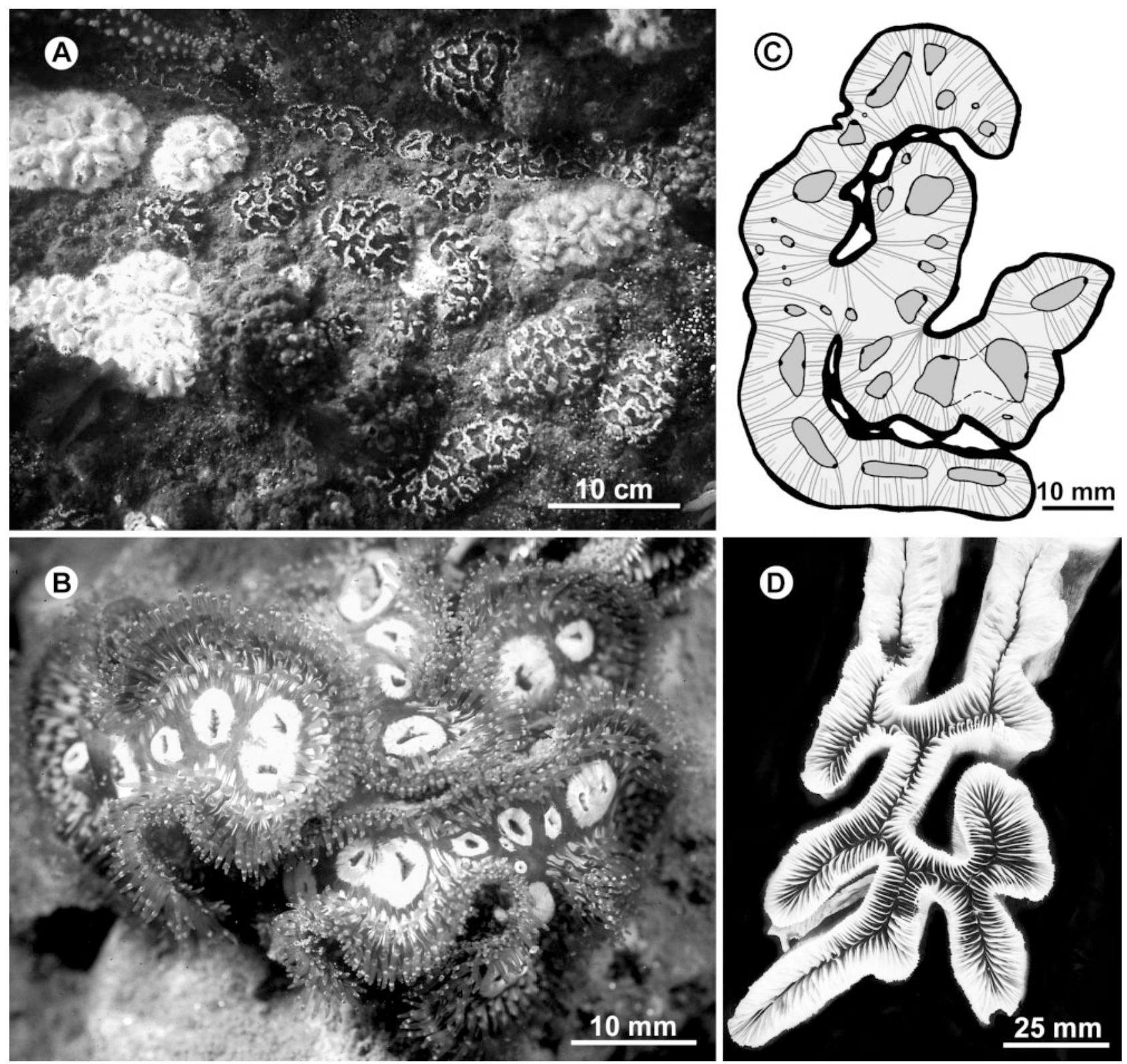

Fig. 1. Colonial sea anemone Cereus herpetodes (A-C) compared with stony coral Euphyllia sp. (D). (A to C) C. herpetodes. (A) Clusters of colonies (Pingueral site, colony at $5 \mathrm{~m}$ depth) locally cover up to $50 \%$ of rocky surfaces. (B) Small colony with 3 tentacular crowns on a common pedal disc; stomodaea marked by white peristomes (aquarium colony). (C) Schematic drawing of cross-section through small colony; black outline: body wall; dark grey areas: pharynxes with siphonoglyphs (black spots); radial lines: perfect and (larger) imperfect mesenteries; dotted lines: oral opening of pharynx in fission. (D) Euphyllia sp. Part of flabellomeandroid colony (photo M. Grasshoff)

this species can be classified as polycentric (Wells \& Hill 1956).

Discussion. A gradual transition from solitary individuals with a single mouth to colonies with many mouths can be seen within the coral family Fungiidae (Veron 2000). We agree with Rosen's (1986) conclusion that scleractinian mouths are homologous, whether they are produced by extratentacular or by intratentac- ular budding. Therefore, each mouth defines a conceptual zooid which according to the taxon is more or less modified, or more or less arrested in its development, and which is sometimes polymorphic (Rosen 1986). Some authors (Wells 1971) prefer to describe the result of intratentacular budding as a polystomodaeal individual. Nevertheless, corals, which regularly exhibit a high number of mouth openings, are generally re- 
garded as colonial (see Rosen 1986, Veron 2000). The morphological prerequisites for Rosen's (1986) interpretation of coloniality are also present in sea anemones. Therefore his conclusions can be applied to sea anemones without further modifications. Sea anemones were considered to be unable to surpass the clearly defined solitary level, with the exception of temporary states during fission and the results of injury. This contradicts findings for Cereus herpetodes.

Specimens of Cereus herpetodes examined by previous authors were observed to have more than 1 oral opening (up to 3: Carlgren 1959; up to 3 large and 9 small: McMurrich 1904; for photographs of type specimens and original drawings see http://hercules.kgs. edu/hexacoral/anemone2/index.cfm), but these authors seemed to be unaware of the fact that they were dealing with colonies. Due probably to the small numbers and sizes of specimens examined, and the lack of in situ or in vivo observations, polystomodaeal specimens of $C$. herpetodes were previously interpreted as being 'in imperfect division' (Carlgren 1959) or 'only a stage in a complete division' (McMurrich 1904).

Coloniality in Cereus herpetodes is a unique feature not shared by the only other species in this genus, C. pedunculatus (Pennant, 1777) from the northern hemisphere. In corals, the mode of budding is usually a generic character. Therefore, in the future, it may be necessary to erect a new genus for the species C. herpetodes.

Shick (1991) posed the question 'Why aren't there any colonial sea anemones?'. He then summarized biomechanical and ecological theories to explain the solitary growth of sea anemones. Francis (1988) and Shick (1991) conclude that sea anemones are an ancient group that, in the sublittoral, adopted the strategy of large individual size and unitary lifestyle at an early stage in response to predation. In intertidal sea anemones, lack of coloniality is explained in terms of mechanical restriction: protection against desiccation such as symmetrical retraction of tentacles, and the retention of coelenteric fluid is interpreted as being more difficult to achieve for closely conjoined members of a sheet-like colony (Shick 1991). As a result, polyps with no exoskeleton should necessarily remain solitary and cylindrical (Grasshoff 1987, Shick 1991, Grasshoff \& Gudo 1998). Our findings suggest that these explanations for the presence or absence of coloniality in anthozoans need to be reconsidered.

As the only known colony-forming sea anemone, Cereus herpetodes is a good subject on which to study the ecological driving forces behind coloniality and its morphological correlates. The flat shape of C. herpetodes colonies and coloniality itself may be an adaptation to a habitat in which extremely strong water movement precludes tall cylindrical growth. Flat growth is frequently observed in sea anemones that are subjected to surf impact or extreme currents (Koehl 1977). Dense aggregations of anemones minimize the dragging effect for each individual (Koehl 1982). The ratio of exposed perimeter to feeding-surface area declines more steeply with clonal growth than with aclonal growth (Francis 1988). Flat colonies of C. herpetodes, which represent the most compact clonal aggregations, consequently attain an optimum ratio. The outer walls of neighbouring sections within a colony of $C$. herpetodes frequently adhere together through the adhesive verrucae on the column, leading to increased stiffness of the colony (Fig. 1C). Resistance against physical removal or damage is increased by particularly strong attachment to the substratum and, in many cases, by the attachment of small stones to the column of $C$. herpetodes and the presence of small stones in the gastrocoel.

The average prey success for each clone mate in dense aggregations with cooperative behaviour is higher than for completely separate individuals of comparable size, as larger and more agile prey can be overpowered and held in such aggregations. In a colony, each zooid benefits from the capture success of its clone mates through exchange of coelenteric fluid.

Predators are often abundant in shallow subtidal water (Paine 1966, Jackson 1985). The frequency of aggressive encounters and their cost to each individual will be lower for a ramet fighting back-to-back with a clone mate than for lone fighters of the same size and shape; more energy can be expended in protecting the exposed sides without increasing total investment (Francis 1988). In Cereus herpetodes, defence mechanisms include fighting tentacles (also termed 'catch tentacles'), acontia, stones in the gastrocoel and stones attached to the outer column wall.

The validity of subdivisions within the Anthozoa has been a subject of debate that has gained in intensity (Fautin \& Lowenstein 1993, Chen et al. 1995, France et al. 1996, Grasshoff \& Gudo 1998, Berntson et al. 1999, Stanley \& Fautin 2001, Won et al. 2001, Daly et al. 2002). The skeletons of Scleractinia are of multiple origin (Romano \& Palumbi 1996, Romano \& Cairns 2000), and may even have been ephemeral. As a result, the lack of coloniality in Actiniaria is one of the last main morphological characters justifying separation of Scleractinia and Actiniaria (Daly et al. 2002). Although Cereus herpetodes exhibits the same mode of colonyformation as some stony corals, from the available data it is not apparent whether, in these sea anemones, coloniality is a plesiomorphic or an apomorphic character. Therefore, conclusions on the phylogenetic position of $C$. herpetodes exclusively based on its coloniality would be premature. Nevertheless, our findings confirm that relationships among anthozoans are not 
clear-cut and support the hypothesis of Stanley \& Fautin (2001) that it may be more phylogenetically accurate to merge the order Scleractinia with the orders Actiniaria and Corallimorpharia.

Acknowledgements. This publication was drawn from the doctoral thesis of V.H. and was supported by a scholarship of the Ludwig-Maximilians-Universität München. We thank Elaine Robson, Martin Thiel, Ralph Tollrian, Michael Schrödl, Roland Melzer, Gerhard Haszprunar, Peter Schuchert, Stephen Cairns, Heide Schulz and Ron Ates for comments on the subject and on previous versions of the manuscript, and Manfred Grasshoff for placing his photograph at our disposal. Thanks to the reviewers for their helpful comments.

\section{LITERATURE CITED}

Berntson EA, France SC, Mullineaux LS (1999) Phylogenetic relationships within the class anthozoa (phylum Cnidaria) based on nuclear 18S rDNA sequences. Mol Phylogenet Evol 13:417-433

Carlgren O (1959) Reports of the Lund University Chile Expedition 1948-49, 38: Corallimorpharia and Actiniaria with description of a new genus and species from Peru. Acta Univ Lunds (N F Avd) 2(56):1-39

Chen CA, Odorico DM, Ten Lohuis M, Veron JEN, Miller DJ (1995) Systematic relationships within the Anthozoa (Cnidaria: Anthozoa) using the 5'-end of the 28S rDNA. Mol Phylogenet Evol 4:175-183

Daly M, Lipscomb DL, Allard MW (2002) A simple test: evaluating explanations for the relative simplicity of the Edwardsiidae (Cnidaria: Anthozoa). Evolution 56:502-510

Dunn DF (1982) Cnidaria. In: Parker SP (ed) Synopsis and classification of living organisms. McGraw-Hill, New York, p 669-705

Fautin DG (1999) Cnidaria. In: Knobil E, Neill JD (eds) Encyclopedia of reproduction. Academic Press, New York, p 645-653

Fautin DG, Lowenstein JM (1993) Phylogenetic relationships among scleractinians, actinians, and corallimorpharians (Coelenterata: Anthozoa). Proc 7th Int Coral Reef Symp 2: 665-670

France SC, Rosel PE, Agenbroad JE, Mullineaux LS, Kocher TD (1996) DNA sequence variation of mitochondrial large-subunit rRNA provides support for a two-subclass

Editorial responsibility: Otto Kinne (Editor),

Oldendorf/Luhe, Germany organization of the Anthozoa (Cnidaria). Mol Mar Biol Biotechnol 5:15-28

Francis L (1988) Cloning and aggression among sea anemones (Coelenterata: Actiniaria) of the rocky shore. Biol Bull (Woods Hole) 174:241-253

Grasshoff M (1987) Sessile Tiere des Meeres; Evolutionswege-Konstruktionen - Lebensräume. Nat Mus 117:369-386

Grasshoff M, Gudo M (1998) Die Evolution der Coelenteraten. II. Solitäre und koloniale Polypen. Nat Mus 128: 329-341

Jackson JBC (1985) Distribution and ecology of clonal and aclonal benthic invertebrates. In: Jackson JBC, Buss LW, Cook RE (eds) Population biology of clonal organisms. Yale University Press, New Haven, CT, p 297-356

Koehl MAR (1977) Effects of sea anemones on the flow forces they encounter. J Exp Biol 69:87-105

Koehl MAR (1982) The interaction of moving water and sessile organisms. Sci Am 247:124-132

McMurrich JP (1904) The Actiniae of the plate collection. Zool Jahrb Abt Syst Ökol Geogr Tiere (Suppl 6):215-306

Paine RT (1966) Food web complexity and species diversity. Am Nat 100:65-75

Pennant T (1777) A British zoology, Vol 4. Benj White, London

Romano SL, Cairns SD (2000) Molecular phylogenetic hypothesis for the evolution of scleractinian corals. Bull Mar Sci 67:1043-1068

Romano SL, Palumbi SR (1996) Evolution of scleractinian corals inferred from molecular systematics. Science 271:640-642

Rosen BR (1986) Modular growth and form of corals. Phil Trans R Soc Lond B 313:115-142

Shick MJ (1991) A functional biology of sea anemones. Chapman \& Hall, London

Stanley GD Jr, Fautin DG (2001) The origins of modern corals. Science 291:1913-1914

Veron JEN (2000) Corals of the world. Australian Institute of Marine Science, Townsville

Wells JW (1971) What is a colony in anthozoan corals? Abstr Program Geol Soc Am 3:748. Reprinted in 1973. In: Boardman RS, Cheetham AH, Oliver WA Jr (eds) Animal colonies: development through time. Dowden, Hutchinson \& Ross, Stroudsburg, p 29

Wells JW, Hill D (1956) Anthozoa-general features. In: Moore RC (ed) Treatise on invertebrate paleontology. Part F: Coelenterata. The University of Kansas Press, Lawrence, KS, p F161-F166

Won JH, Rho BJ, Song JI (2001) A phylogenetic study of the Anthozoa (phylum Cnidaria) based on morphological and molecular characters. Coral Reefs 20:39-50

Submitted: July 8, 2002; Accepted: March 6, 2003

Proofs received from author(s): July 4, 2003 